\title{
THE EFFECTIVITY OF THE LIBRARY PROMOTION TO THE LIBRARY VISITOR GROWTH IN THE LIBRARY OF HASANUDDIN UNIVERSITY MAKASSAR
}

\author{
Ida Jayanti ${ }^{1}$ \\ M. Najib ${ }^{2}$ \\ Arifuddin Tike ${ }^{3}$ \\ Alauddin State Islamic University of Makassar ${ }^{1,2,3}$ \\ E-mail:idha.jayanti26@gmail.com
}

\begin{abstract}
This research is aimed to discover the effectiveness of the library promotion to the growth of the library visitors in the library of Hasanuddin University. This is an associative research with quantitative approach. The population used in this research is the students of Hasanuddin University visiting the central library during 2018 which reached 102.594 visitors in total, while the samples of this research covered only 203 respondents. Research data is collected using both printed and online questionnaire. Hence, the data is processed and analyzed using correlativity test and validity test. According to the testing result, the effectivity of the library promotion variable $(X)$ related to the increase of the library visitors' growth $(Y)$ in the central library of Hasanuddin University is feeble, with the Pearson correlation value takes only 0,139 or $13,9 \%$ and the significancy rate is at $0,000<0,05$. These numbers indicates the library promotion variable $(X)$ is simultaniously affecting the visitor rate variable $(Y)$ around $19 \%$, while the rest $81 \%$ is affected by another variables apart from regression equation and other variables.
\end{abstract}

Keywords: Library; Library promotion; Library visitor

\section{INTRODUCTION}

Library has to be ready to sustain the need of information as the demand of library users of information escalates. It needs to introduce, enrich collections, infrastructure, accessibility as well as brand new features pioneered by the library in order to utilize the library more.

Vast library colleection would be ineffective if the library is poor-utilized. Therefore, attracting potential and non-potential library users is a neccessity to make library more useful. The more visitor of a library, the better the library utilization would be. Hence, it is essential for the library to introduce itself not only to the users but also but also to the broader audience through promotion of library (Binalay, 2016).

Promotion is a bridge between organization and consumer that provides information regarding to the products and services offered by one's organization. Without promotion, that product or service will be no use. According to Quraisy Mathar, library promotion is aimed to scope the users who are unaware about the information that they actually need. That is why, library promotion needs to be delivered by library staff to the users. Promotion is the most effective way to promote a product using various strategies (Muh. Quraisy Mathar, 2011: 61). The library service, however, depends on the user needs.

Based on the regulation of the Republic of Indonesia No. 24 year 2014 about the implementation of the Constitution No. 43 of 2007 regarding to Libraries. Article 30 section 1 mentioned that library service promotion is intended to highlight the image of 
library as well as to encourage people to read books. Library service promotion is conducted continuously (Republic of Indonesia, 2014: 15).

Hasanuddin University's central library is one of the higher education in Indonesia that preserves tridharma of higher education. The library has been conducting promotions to attract visitors such as; library introductory to the fresh undergraduate students, spreading leaflet/brochure, pamphlet/banner, performing exhibition, competition and seminar, social media promotion (Facebook, Instagram, Twitter, Whatsapp, and Youtube) and library website, conducting user education and library tour.

According to the observation done by the researcher, however, it is found that Central Library of Hasanuddin University Makassar is relatively low compared to the previews years in 2018 that reached 102,594 visitors, (there were 31.571 students in total). The aim of this research is to figure out how much the library promotion affects the library visitor in the Central Library of Hasanuddin University Makassar.

\section{RESEARCH METHODS}

Qualitative research is a research specialized to analyze numerical data. The researchers use statistical descriptive research with quantitative approach. It is used to describe objects of research trough sample data or population obtained on the field. The research took place in Central Library of Hasanuddin University Makassar, and the population mentioned above is a dynamic population.

The research samples is all Hasanuddin University students who visited Central Library of Hasanuddin University Makassar around 203 respondents. The data is collected throughout observation, questionnaire and documentation. The questionnaire itself was the main instrument of data collection. Validity and reliability test is conducted by using IBM SPSS v.22. and the data analyses is applied using correlative and regressive test from SPSS.

\section{RESEARCH RESULTS}

Data is analyzed based on the questionnaire given to the 203 respondents in the Central Library of Hasanuddin University Makassar. Those respondents is consisted of 106 males and 97 females. For the record, this research is focused only to the library promotion and libarry visitors in the Central Library of Hasanuddin University Makassar.

Based on the data processing result for library promotion variable (x) which has total 14 questions, the score for this variable is 11.437. According to the answers taken from 203 respondents, the score value for library promotion variable reached 13.551 between the scale of 2.842-14.210. These number is classified between the interval good and close to very bad. From the scale calculation result, we concluded that there is an evidence in which the library visitors is affected by how the Central Library of Hasanuddin University Makassar conducting promotions.

As for the library visitatorial variable (y) for the promotion by the Central Library of Hasanuddin University Makassar, there are total 8 questions. According to all 203 respondents, this variable score is 1.299 between the scale of 1.624-8.120. Referring to this scale, the score can be categorized in interval between bad and close to very bad. This means that library promotion has no effect for the visitors.

To find out how the library promotion affects the growth of library visitor in the Central Library of Hasanuddin University Makassar, the correlation test result finds that the correlation is appeared in the Pearson correlation value between Library Promotion 
variable $(\mathrm{X})$ and visitor rate $(\mathrm{Y})$ for about 0,139 . This means that the interval is between $0,000-0,199$. From that point we can conclude that the correlation between two variables are weak.

From the regression analysis, the equation of library promotion $(\mathrm{X})$ to the library visitatory $(\mathrm{Y})$ is as follows $\mathrm{Y}=14046+0,048 \mathrm{X}$. This indicates that if there were no significant promotion in the library, the visitor rate would be steady in the score 14.046. The more significant the promotion, the higher the rate of the visitors in the library, vice versa.

Meanwhile, the hypothetical test result from this research is that the regression test result shows the beta value of library promotion to the visitor increase is 0,139 with significancy rate $0,000<0,05$. Therefore, it can be concluded that the library promotion can affect the visitor rate. The coefficient result of the library promotion determination to the visitor increase is 0,019 . In the other word, the library promotion affects inasmuch as $19 \%$ to the visitor, whereas the other $81 \%$ is affected by another variables.

\section{CONCLUSION}

Correlation test result shows the score 0,139 with the interval of $0,000-0,199$. From this output, we can see that there is a weak relation between library promotion to the visitor in the central library of Hasanuddin University Makassar. The significancy rate is $0.000<0,05$ that the proof is strong enough to decline $\mathrm{H} 0 ; \mathrm{p}=0$ and approve $\mathrm{H} 1 ; \mathrm{p} \neq$ 0 to have the significant correlation.

The percentage of library promotion effectiveness to the visitor rate is $19 \%$. This implies that as the library promotion is increased, the visitor would grow as well. The other $81 \%$ is affected by other unidentified variables.

\section{IMPLICATION}

This research is expected to be a refference for another library promotion-related topic research. This topic is very fundamental for librarianship. The topic of library promotion is the best topic to boost visitor to the libraries.

\section{REFERENCE}

Arsita, D. A. (2016) 'Hubungan Kepuasan Layanan Perpustakaan dengan Minat Kunjung Siswa ke Perpustakaan SMA Negeri 3 Mojokerto', Jurnal Inspirasi Manajemen Pendidikan, 4(1), pp. 1-6. Available at: https://jurnalmahasiswa.unesa.ac.id/index.php/inspirasi-manajemenpendidikan/article/view/17667 (Accessed: 30 October 2019).

Binalay, A. (2016) 'Manfaat Promosi Perpustakaan Pada Mahasiswa Fispol Dalam Meningkatkan Jumlah Pemustaka Di Upt Perpustakaan Universitas Sam Ratulangi', Acta diurna, 3(3). Available at: https://www.neliti.com/publications/89543/manfaat-promosi-perpustakaan-padamahasiswa-fispol-dalam-meningkatkan-jumlah-pem (Accessed: 30 October 2019). 
Habir, H. (2015) 'Pengaruh Layanan Perpustakaan Terhadap Minat Kunjung Pemustaka di Perpustakaan STIKES Mega Rezky Makassar', Khizanah al-Hikmah : Jurnal Ilmu Perpustakaan, Informasi, dan Kearsipan. Universitas Islam Negeri Alauddin Makassar, 3(2), pp. 156-171. doi: 10.24252/kah.v3i2a5. 